\title{
KEY FACTORS FOR THE IMPROVEMENT OF SMALLHOLDER FARMERS' PARTICIPATION IN AGRO-PROCESSING INDUSTRIES OF GAUTENG PROVINCE OF REPUBLIC OF SOUTH AFRICA: LESSONS FOR THE EXTENSION ADVISORY SERVICES
}

\author{
Mmbengwa, V.M. ${ }^{1}$, Rambau, K. ${ }^{2}$, Rakuambo, J .N. ${ }^{3}$ and Qin, X.4 \\ Corresponding author: V.M. Mmbengwa Email: VMmbengwa@namc.co.za
}

\begin{abstract}
This study aims at identifying factors that could be used as parameters to improve the smallholder farmers' participation in the agro-processing industries of Gauteng province in order to enhance job creation and self-employment. The study used both qualitative and quantitative research approaches. The focus sessions were used to exploit the respondents' views regarding their participation or lack thereof. On the other hand, the quantitative approaches were used to quantify the effect of the factors under consideration. A sample of ( $n$ $=78)$ smallholder farmers were purposively selected across ten $(n=10)$ local municipalities. The data were analysed using a logistic regression model where non-participation and participation were coded 0 and 1 , respectively. The effect of profit, access to advice, age of the farmers, and information flow to the participation of the smallholder farmers was tested. The study found that five identified parameters \{information supply (beta $=0.315, p=0.002$ ), bonds $($ beta $=0.332, p=0.000)$, mutual trust (beta $=0.410, p=0.000)$, age $($ beta $=0.242, p$ $=0.004)$ and access to study group (beta $=-0.416, p=0.000)\}$ have significant probabilities to improve the participation of smallholder farmers in the agro-processing sub-sector. The results imply that extension advisors and policymakers can use these parameters to improve the participation and representativeness of the smallholder farmers in the agro-processing industries.
\end{abstract}

Keywords: agro-processing, smallholder, participation, sector, factors

\section{INTRODUCTION}

Agro-processing is referred to as the activities that change the form of agriculture, forestry, and fisheries products into various forms to facilitate more comfortable handling and often increase shelf life and market access (DAFF, 2016a). Other authors refer to agro-processing as a set of techno-economic activities carried out for conservation and handling of agricultural produce and to make it usable as food, feed, fiber, fuel, or industrial raw material (Gebrehiwet and Mathibeli, 2013). All these definitions make it clear that agro-processing does not have a single

\footnotetext{
${ }^{1}$ Manager, Smallholder Market Access Units, National Agricultural Marketing Council (NAMC), 536 Francis Baard, Pretoria, 0002, Republic South Africa, Email: VMmbengwa@ namc.co.za, ORCID: 0000-0002-7618-9925

${ }^{2}$ Research officer, Smallholder Market Access at the National Agricultural Marketing Council (NAMC), P/Bag x 935, Block A, 4th Floor, Arcadia, 0002. Tel. 0123411115; E mail: KRambau@ namc.co.za

${ }^{3}$ Production scientist, Research at Gauteng Department of Agriculture \& Rural Development, 56 Eloff, Umnotho House, JOHANNESBURG 2000, tel: 011240 3130, E mail: JULIET.RAKUAMBO@gauteng.gov.za

${ }^{4} \mathrm{PhD}$ Student, University of Pretoria and CEO of ACASA, Association of China-Africa Small-holder Agriculture: GSTM, University of Pretoria, Provate Bag X20, Hatfield, 0028 . Tel. 076829 2606; E mail: xiaoshun.qin2020@gmail.com/xiaoshun.qin@acasa.org.za, ORCID: 0000-0002-5938-4753
} 
universal definition in the agricultural sector. Mazungunye (2019); Owoo, and LambonQuayefio (2018), and Black, et al., (2020) have reported that agro-processing has the potential to provide a bridge from primary agricultural products to industrialization while increasing the demand for the agricultural products and opportunities for rural employment.

In countries like Ethiopia, Tanzania, Kenya, South Africa, and Ghana, up to hundreds of thousands of workers are employed by fresh fruit and vegetables (FFV) export companies (Feyaerts et al., 2020). According to these authors, contract farming with the agro industries and smallholder farmers had a significant impact on the rural employment and poverty alleviation. Despite limited access to land and the related agro-ecological conditions including lack of access to water, as well as socio-political and spatial dimensions, smallholder tree-crop farming's in agro-processing industries key to rural economic development (Olofsson, 2020). The importance of agro-processing industrialization in the South African economy in relation to smallholder farmers cannot be underestimated (DAFF, 2012). Its' reported contribution to the GDP of approximately R49-billion in 2013 makes it a significant player in the macroeconomic sphere of South Africa (BrandSA, 2014). Thus, this industry is amongst the industries identified by the Industrial Policy Action Plan (IPAP), the New Growth Path and the National Development Plan (NDP) for its potential to spur growth and create jobs because of its perceived strong backward linkage with the primary agricultural sector (DAFF, 2016).

According to the reports from the Department of Agriculture, Forestry, and Fisheries (DAFF), the agro-processing industry is economically resilient (DAFF, 2016a). However, during the third quarter of 2016, it has shed 2624 jobs in the food, furniture, footwear, textiles, and leather products (Dimant et al., 2016, DAFF, 2016a). Although job losses had occurred, some agroprocessing industries managed to create jobs in the beverages and tobacco, wearing apparel, wood and wood products, paper and paper products, and rubber divisions in the same industry (DAFF, 2016a). While this industry could be vulnerable to the economic downturn, it undoubtedly plays a significant role in job creation and sustainability of the economy. This industry is one of the industries that have the potential to alleviate poverty in South Africa.

Gauteng province is deemed to be the economic hub with negligible primary agricultural production (GDARD, 2015; Dimant et al., 2016). The province is a host of numerous industries and the agro-processing industry being one of them. This hosting makes the province integral in its quest to promote transformation in the participation of agro-processing industries. The existence of smallholder farming in Gauteng is severely constrained by the shortage of land and high land purchase prices (Dimant et al., 2016). With growing immigration in Gauteng Province, the need for smallholding farming for food security and job creation is inevitable. This study seeks to determine parameters that could be used to improve the smallholder farmers' participation in the agro-processing industries in Gauteng Province in order to enhance job creation and self-employment.

\section{PROBLEM STATEMENT}

According to Gauteng agro-processing strategies, South Africa's agro-processing activities are concentrated in the Gauteng Province (GDARD, 2015). It had the most substantial agroprocessing value addition (28.5\%) and significant job creation (23\% or 124000 jobs) in 2013 (GDARD, 2015). The challenges are that this industry is not transformed, and the agroprocessing industry participants still do not reflect the demographic representation of the province and the country at large. Gauteng agro-processing strategies characterize this industry 
as dominated by a few large players that own large proportions of the market share (GDARD, 2015). There seem to be a few new role-players, which are the smallholder farming sector, and black entrepreneurs who are participating in this industry (Dimant et al., 2016). These new role players face challenges of poor access to agro-processing markets, technologies, skills, inadequate infrastructure, and limited growth incentives. These further hinder the entry and growth of smaller processors into the market. Consequently, they fail to progress to the agroprocessing industry. Thus, participation in this industry appears to be skewed toward the previously advantaged individual entrepreneurs who often see the new entrepreneurs as a threat.

\section{CONTEXTUALIZATION OF THE STUDY}

South African Government has found it challenging to transform the agro industries to include smallholder-farming entrepreneurs. Thus, Khoza et al. (2019) reported that smallholder farmers in South Africa had not been linked successfully to sustainable agro-processing value chains. Currently, commercial agriculture is the leading player in the agro-processing industries in South Africa, whereas smallholder farmers play a limited role despite receiving support from the Government (Khoza et al., 2019 and Mmbengwa et al., 2011). The lack of linkages to these chains had various productive and economic implications for the whole smallholder farming fraternity, including the extension advisory services whose critical roles are to advise the farmers to access opportunities in their respective commodity sub-sectors.

Baloch and Thapa (2019) reported that the roles of the extension services are associated with the training, visiting farmers, transferring Technology (ToT), Farmer Field Schools, conducting agricultural research, and extension services in promoting sustainable agriculture development. According to Cai et al. (2020), agricultural extension services are an essential way of spreading new technologies. These authors reported the significant growth of Chinese agricultural technologies because of the role that the extension services played. This evidence explains why China's agricultural extension is dominated by the Public Agricultural Extension System (PAES), which provides agricultural extension services with widely distributed Government institutions and a multitude of extension agents' networks (Hu et al. 2010, 2009; Hu et al. 2012).

Mabe and Oladele (2020) reported that in Africa, most farming communities rely on the public Agricultural Extension services for technical farming advice and information to induce agricultural development activities. (Hu et al. 2004; Huang, Yang and Rozelle 2010). Given this context, it could be induced that South African extension services have significant tasks in changing the agro industries' profile.

\section{RESEARCHMETHOD}

\subsection{Participants and procedure}

The participants were smallholder farmers from Gauteng Province in the Republic of South Africa. The Gauteng Department of Agriculture Rural Development (GDARD) granted permission to solicit their participation in the cross-sectional survey. Before the permission was granted, the research team had to present the research proposal to GDARD, followed by all regional GDARD offices, extension workers, and to the smallholder farmers themselves. In this study, seventy-eight $(\mathrm{n}=78)$ smallholder farmers participated in the survey. Men comprised 
$53.85 \%(n=42)$ of the sample whilst women respondents constituted $46.15 \%(n=36)$. The mean age of the smallholder farmers who participated was found to be 53 years old $(\mathrm{SD}=$ 14.514). The youngest participant was 23 years old, while the oldest was 83 years old. The majority of the participants come from Emfuleni local municipality $\{26(33.3 \%)\}$, followed by Ekurhuleni $\{21(26.92 \%)\}$ and Mid-Vaal $\{17(21.79 \%)\}$.

\subsection{Materials and Methodology}

During data collection, the study used qualitative and quantitative methodologies. For qualitative data collection, focus group sessions and official meetings were used. The purpose of using the qualitative approach in this study was to enrich the discussion. Furthermore, it was to discover new narratives on the phenomenon under consideration with the view to unearthing the practical experiences of the participants. This exercise was essential to reveal the actual reality. On the quantitative data collection, the study used a close-ended questionnaire. The purpose of this quantitative research design was to enable researchers to conduct both descriptive and explanatory (inferential) analyses. Before the collection of quantitative data collection, the draft questionnaire was piloted and also evaluated by industry experts to ensure its reliability and validity.

\subsection{Measurement of variables}

In this study, participation (dependent variable) was measured as a binary response variable where zero (0) stands for nonparticipation, and one (1) stands for participation in agroprocessing. Nonparticipation in agro-processing is used as a baseline. The explanatory variables which were regarded as the parameters to enhance participation of smallholder farming in this study were measured on the five-point Likert scale $(1=$ strongly agree to $5=$ strongly disagree).

Table 1: Factors hypothesized to influence participation of smallholder farmers in agroprocessing in Gauteng province

\begin{tabular}{|c|c|c|c|}
\hline $\begin{array}{l}\text { Variable } \\
\text { name }\end{array}$ & Description of Variables & Measurements & $\begin{array}{l}\text { Expected } \\
\text { sign }\end{array}$ \\
\hline $\begin{array}{l}\text { Dependent } \\
\text { Variable } \\
\text { Participation }\end{array}$ & $\begin{array}{l}\text { Are you participating in the agro- } \\
\text { processing industry }\end{array}$ & $\begin{array}{l}(1=\text { Participating, } 0=\text { Not } \\
\text { participating) }\end{array}$ & + \\
\hline \multicolumn{4}{|c|}{ Explanatory Variables } \\
\hline $\begin{array}{l}\text { Information } \\
\text { Supply }\end{array}$ & $\begin{array}{l}\text { I do get information from the agro- } \\
\text { processing industry sector? }\end{array}$ & $\begin{array}{l}(1=\text { Strongly agree }-5= \\
\text { Strongly disagree })\end{array}$ & - \\
\hline Bonds & $\begin{array}{l}\text { Participation in agro processing } \\
\text { increase the chances of getting } \\
\text { bonds. }\end{array}$ & $\begin{array}{l}(1=\text { Strongly agree }-5= \\
\text { Strongly disagree })\end{array}$ & + \\
\hline Mutual trust & $\begin{array}{l}\text { Mutual trust improves } \\
\text { participation in agro-processing. }\end{array}$ & $\begin{array}{l}(1=\text { Strongly agree }-5= \\
\text { Strongly disagree })\end{array}$ & + \\
\hline Age & $\begin{array}{l}\text { Aging improve participation in } \\
\text { agro-processing. }\end{array}$ & Number & - \\
\hline $\begin{array}{l}\text { Access to study } \\
\text { group }\end{array}$ & $\begin{array}{l}\text { Access to study groups improve } \\
\text { participation in agro-processing. }\end{array}$ & $\begin{array}{l}(1=\text { Strongly agree }-5= \\
\text { Strongly disagree })\end{array}$ & - \\
\hline
\end{tabular}

Source, Survey, 2017 


\subsection{Data analysis}

The study used descriptive and correlational analysis to determine the means, standard deviation, and the correlation coefficient of the responses variables. On the inferential analysis, the study used a stepwise multiple logistic regression model where non-participation and participation were coded 0 and 1, respectively. The effect of profit, access to advice, age, and information flow to the participation of the smallholder farmers was tested. A backward elimination strategy was used to remove access to the study group from model B. This is elimination was informed by the assumption that all smallholder farmers have an equal probability of accessing the study group provided they are registered with Gauteng Department of Agriculture Rural Development.

\subsection{Analytical framework}

Stepwise multiple logistic regression models were used to assess the participation of smallholder farmers in agro-processing in Gauteng Province. The general form of the logit model is:

$P\left[y_{i}=1 \mid x_{i}\right]=G\left(x_{i}, \beta\right)$

Where is the standard logistic distribution function which takes values between 0 and 1 (Verbeek, 2012). Equation (1) can be re-written in terms of odds ratios, as shown in equation (2):

$$
\log \frac{p_{i}}{1-p_{i}}=x_{i}^{\prime} \beta \quad \text { or } \quad \frac{p_{i}}{1-p_{i}}=\exp \left(x_{i}^{\prime} \beta\right)
$$

Where $p_{i}$ is the probability of observing the outcome $y_{i}=1$ (participation and $p_{i} / 1-p_{i}$ ) is the odds ratio which is equivalent to exponential coefficients. The odds ratio can be interpreted as the number of times by which the odds of the outcome $y_{i}=1$ will be higher than the odds of the outcome $y_{i}=0$ (non- participation) if the $j^{\text {th }}$ predictor increases by one unit. However, to see the effect of an explanatory variable on the probability of being a participant $\left(p_{i}\right)$, the marginal effects are estimated.

The empirical formulation of the model $\mathrm{A} \& \mathrm{~B}$ (participation) used in the analysis was:

Participation $_{A}=$ Constants $+\beta_{1} I S+\beta_{2}$ Bonds $+\beta_{3} M T+\beta_{4} A g e+\beta_{5} A S+\varepsilon_{i}$

Where:

- $\mathrm{Y}$ is a dummy dependent variable, $=1$ if event happens, $=0$ if event does not happen,

- $\boldsymbol{a}$ is the coefficient on the constant term,

- $\quad \beta$ is the coefficient(s) on the independent variable(s),

- $I S$ is the information supply

- $M T$ is the mutual trust

- $A$ Sis the access to study group

- $\mathrm{E}_{\mathrm{i}}$ is the error term.

Participation $_{B}=$ Constants $+\beta_{1} I S+\beta_{2}$ Bonds $+\beta_{3} M T+\beta_{4}$ Age $+\varepsilon_{i}$

Participation was the dependent variable taking the value of 1 if individual $i$ was a participant and 0 if a non-participant. The explanatory variables are as described in Table 1. Equations (3\&4) and Odds Ratios were estimated using STATA 12. 


\section{RESULTS ANDDISCUSSION}

\subsection{Descriptive and correlational analyses}

Table 2 shows the results of the mean, standard deviation, and relationship between response variables that were analysed using Pearson's product-moment correction coefficient (Pearson's r) after a normality test was performed.

Table 2: Means, standard deviation and inter-correlations of explanatory variables

\begin{tabular}{|c|c|c|c|c|c|c|c|}
\hline Explanatory variables & Mean & SD & (1) & $(2)$ & (3) & (4) & (5) \\
\hline Information supply (1) & 3.641 & 1.377 & 1.000 & & & & \\
\hline Investment (bonds) (2) & 3.936 & 1.073 & $\begin{array}{l}0.327 * * \\
(0.004)\end{array}$ & 1.000 & & & \\
\hline Mutual Trust (3) & 0.744 & 0.439 & $\begin{array}{l}0.383 * * * \\
(0.001)\end{array}$ & \begin{tabular}{|l|}
0.323 \\
$(0.004)$
\end{tabular} & 1.000 & & \\
\hline Age (4) & 52.667 & 14.514 & $\begin{array}{l}0.143 \\
(0.210)\end{array}$ & \begin{tabular}{|l|}
0.095 \\
$(0.406)$ \\
\end{tabular} & $\begin{array}{l}0.151 \\
(0.186)\end{array}$ & 1.000 & \\
\hline Access to study groups (5) & 3.564 & 1.410 & $\begin{array}{l}0.587 * * * \\
(0.000)\end{array}$ & $\begin{array}{l}0.341 * * \\
(0.002)\end{array}$ & $\begin{array}{l}0.341 * * \\
(0.002)\end{array}$ & $\begin{array}{l}0.254 * * \\
(0.025)\end{array}$ & 1.000 \\
\hline
\end{tabular}

Notes: $\mathrm{N}=78, *=\mathrm{P}<0.05, * *=\mathrm{P}<0.01, * * *=\mathrm{P}<0.001$

This test was done to test the linearity of the response variable. From the results, it was clear that moderate positive statistically significant correlations between bonds and information supply $\{\mathrm{r}(78)=0.327, \mathrm{p}=0.004\}$, and between mutual trust $\{\mathrm{r}(78)=0.383, \mathrm{p}=0.001\}$ and positive highly statistical significant correlation between access to study group and information supply $\{\mathrm{r}(78)=0.587, \mathrm{p}=0.000\}$ were observed. It appears that access to study group has a positive statistical significant correlation with bonds $\{\mathrm{r}(78)=0.341, \mathrm{p}=0.002\}$, mutual trust $\{\mathrm{r}(78)=0.341, \mathrm{p}=0.002\}$, and age $\{\mathrm{r}(78)=0.254, \mathrm{p}=0.025\}$. Based on the evidence above, there is a positive inter-relationship between some explanatory variables. This relation implies that there are some parameters which could be increased when increasing the others. 


\subsection{Inferential Analysis}

\subsubsection{Causal effects of the response variables}

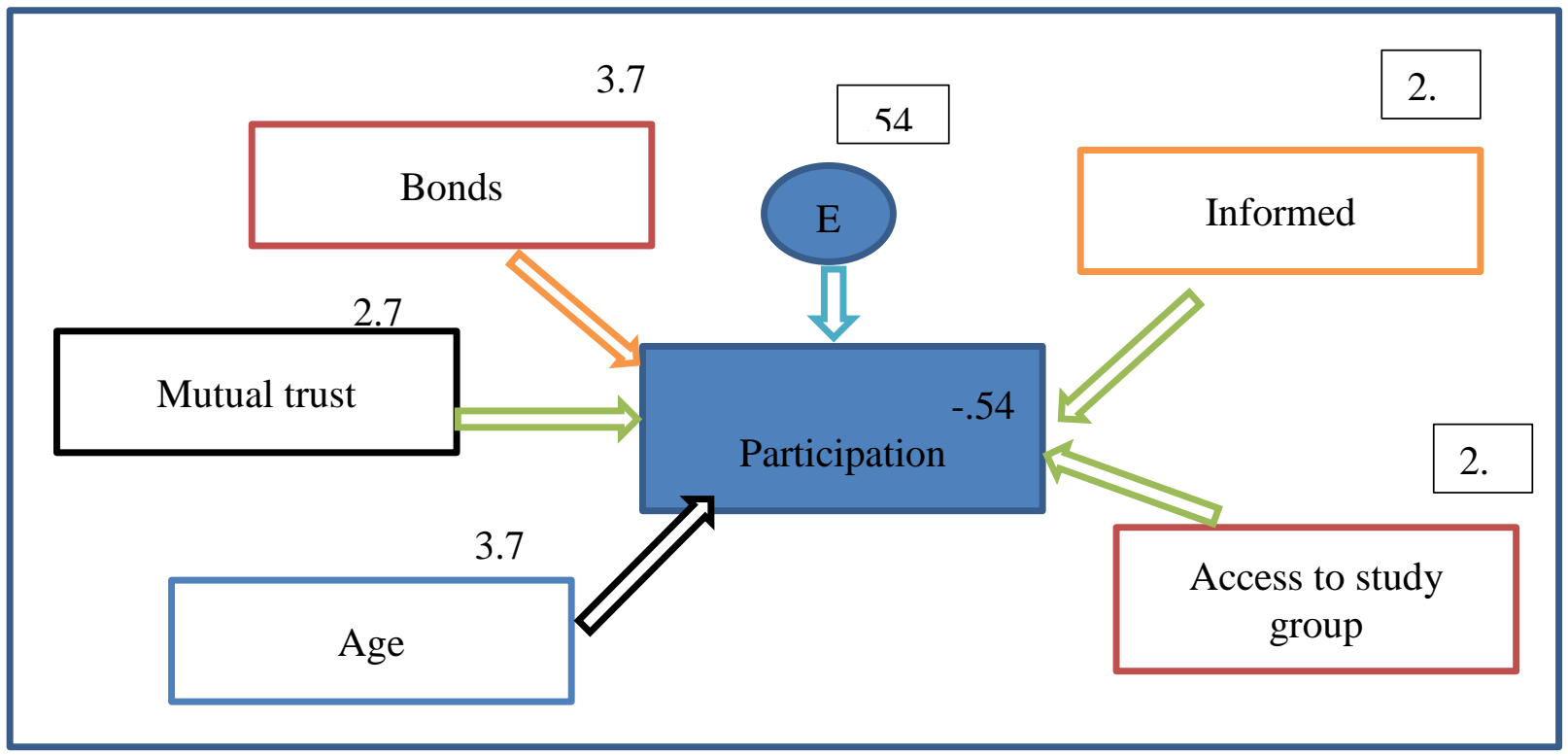

Fig. 1 The path way diagram for the tools that cause of the smallholder farmers participation in the agro-processing industries

Table 3 and Figure 1 present the results of the causal effects for agro-processing industries in Gauteng Province.

Table 3: Causal effect of tools that can improve participation in the agro-processing industries of Gauteng Province

\begin{tabular}{|l|l|l|l|l|}
\hline Standardized & Coeff $(\boldsymbol{\beta})$ & Beta & P> I z I & $\begin{array}{l}\text { 95\% Conf. } \\
\text { Interval }\end{array}$ \\
\hline Information supply & $\begin{array}{l}0.091^{* * *} \\
(0.031)\end{array}$ & $\begin{array}{l}0.315^{* * *} \\
(0.102)\end{array}$ & 0.002 & $0.116-0.514$ \\
\hline Bonds & $\begin{array}{l}0.123^{* * *} \\
(0.037)\end{array}$ & $\begin{array}{l}0.333^{* * *} \\
(0.095)\end{array}$ & 0.000 & $0.146-0.520$ \\
\hline Mutual Trust & $\begin{array}{l}0.370^{* * *} \\
(0.084)\end{array}$ & $\begin{array}{l}0.410^{* * *} \\
(0.085)\end{array}$ & 0.000 & $0.245-0.576$ \\
\hline Age & $\begin{array}{l}0.006^{* * *} \\
(0.002)\end{array}$ & $\begin{array}{l}0.242^{* * *} \\
(0.083)\end{array}$ & 0.004 & $0.079-0.405$ \\
\hline $\begin{array}{l}\text { Access to study } \\
\text { group }\end{array}$ & $\begin{array}{l}-0.117 * * * \\
(0.033)\end{array}$ & $\begin{array}{l}-0.416^{* * *} \\
(0.111)\end{array}$ & 0.000 & $-0.634-0.198$ \\
\hline Constant & -0.214 & -0.538 & 0.192 & $-1.358-0.273$ \\
\hline $\begin{array}{l}\text { Var } \\
\text { (e.participation) }\end{array}$ & $\begin{array}{l}(0.172) \\
(0.083\end{array}$ & $\begin{array}{l}0.538 \\
(0.073)\end{array}$ & & \\
\hline
\end{tabular}

Legend: $*=\mathrm{P}<0.05, * *=\mathrm{P}<0.01, * * *=\mathrm{P}<0.001$

According to these results, it was found that the following parameters: information supply (beta $=0.315, p=0.002$ ), bonds (beta $=0.332, p=0.000)$, mutual trust $($ beta $=0.410, p=0.000)$ and 
age (beta $=0.242, p=0.004$ ) significantly caused participation of smallholder farmers in the agro-processing to occur. Interestingly, the results showed that access to the study group (beta $=-0.416, p=0.000$ ) has a negative causal effect on the participation of these farmers. These effects imply that access to the study group hinders the smallholders from participating in agroprocessing industries.

\subsubsection{Effects of key parameters on agro-processing industry participation}

The results in table 4 show that in all of the models under consideration, the predictors' variables are jointly significant.

Table 4 Factors affecting smallholder farmers' participation in agro-processing in Gauteng province

\begin{tabular}{|c|c|c|c|c|}
\hline VARIABLES & MODEL A & & MODEL B & \\
\hline $\begin{array}{l}\text { INDEPENDENT } \\
\text { VARIABLES }\end{array}$ & $\begin{array}{l}\text { ODDS RATIO (CI- } \\
95 \% \text { ) }\end{array}$ & $\mathbf{Z}$ & $\begin{array}{l}\text { ODDS RATIO (CI- } \\
95 \%)\end{array}$ & $\mathbf{Z}$ \\
\hline Information supply & $\begin{array}{l}2.490 * * * \\
(1.189-5.214)\end{array}$ & 2.42 & $\begin{array}{l}1.797 * \\
(0.971-3.323)\end{array}$ & 1.87 \\
\hline Investment (Bonds) & $\begin{array}{l}3.893 * * * \\
(1.391-0.888)\end{array}$ & 2.59 & $\begin{array}{l}3.023 * * \\
(1.145-7.981)\end{array}$ & 2.23 \\
\hline Mutual Trust & $\begin{array}{l}14.101 * * * \\
(2.202-0.290)\end{array}$ & 2.79 & $\begin{array}{l}8.979 * * * \\
(1.930-41.767)\end{array}$ & 2.80 \\
\hline Age & $\begin{array}{l}1.082 * * * \\
(1.007-1.162)\end{array}$ & 2.16 & $\begin{array}{l}1.074 * * \\
(1.002-1.151)\end{array}$ & 2.03 \\
\hline Access to study group & $\begin{array}{l}0.397 * * \\
(0.155-1.014)\end{array}$ & -1.93 & & \\
\hline Constant & $\begin{array}{l}0.000 * * * \\
(3.43-.060)\end{array}$ & -2.87 & $\begin{array}{l}0.000 * * * \\
(2.76-.058) \\
\end{array}$ & -2.87 \\
\hline Number of observations & 78 & & Number of observatio & 78 \\
\hline Model A (LR chi2(4) & 33.73 & & Model B (LR chi2(4) & 33.73 \\
\hline Prob > chi 2 & 0.000 & & Prob > chi2 & 0.000 \\
\hline Pseudo R-Squad & 0.503 & & Pseudo R-Squad & 0.441 \\
\hline LRtest: LR chi2(1 & 4.76 & & & \\
\hline Prob $>$ chi $2=$ & 0.0292 & & & \\
\hline
\end{tabular}

Legend: $*=\mathrm{P}<0.05, * *=\mathrm{P}<0.01, * * *=\mathrm{P}<0.001$

In other words, in both model A and B \{Model A (LR chi2 $(4)=33.73$, Prob $>$ chi2 $=0.000)$ and Model B (LR chi2 $(4)=33.73$, Prob > chi2 = 0.000) $\}$, the null hypothesis of no joint significance of the predictor variables is not supported. These findings imply that all the predictor variables jointly influence or explain the dependent variables. Therefore, there is a correlation between participation and the predictor variables in question. In the sample, we failed to accept the null hypothesis that information supply, bonds (Investment), mutual trust, age, and access to study groups do not influence or predict the participation of smallholder farmers in the agro-processing industries.

This result seems to imply that all the predictor mentioned above variables are significant to influence whether the smallholder farmers participate (or not participate) in the agroprocessing. In model A, it was found that access to the study group was the only predictor 
variable that harms the participation of smallholder farming in agro-processing industries in Gauteng Province. On the other hand, in model B, all the predictor variables under considerations were found to have a positive effect on the smallholder farmers' participation in agro-processing. Concisely, model (A and B) have 0.503 and 0.441 pseudo R-squad. This result implies that the expression of the variability in model $\mathrm{B}$ of smallholder farmers' participation is reduced by 0.062 because of the exclusion of the access to study group variables is realized. This result could be observed by the reduction in the odds ratios of the parameters that determine the participation.

\section{a) Effect of mutual trust in the smallholder farmers' participation}

Mutual trust is essential in facilitating the co-operative behavior of entrepreneurs (Thindisa, 2014). The current study sought to determine whether the mutual trust has an influence on the participation of smallholder farmers' in the agro-processing industries. In model A, the results showed that mutual trust was 14.101 times more likely to significantly influence participation of smallholder farmers in agro-processing when other confounding variables are held constant. On the other hand, the results in model B showed the significant reduction in the odds ratio of 5.122 times (that is from 14.101 to 8.979 odds ratio). This may imply that although mutual trust is significantly critical in determining the participation of smallholder farmers in agroprocessing, its impact heavily depend on the inclusion of the access to study group predictor variable. The exclusion of access to study group variable seems to have a negative effect on the mutual trust variable and thus reduced the effect on the participation of smallholder farming in the agro-processing industries.

\section{b) Effect of age on the smallholder farmers' participation}

Current research findings have shown that age plays an integral part in productivity of the smallholder farming enterprises (Oladele 2011 and Maponya et al., 2014). In this type of farming, age is associated with the level of farming experience (Maponya et al., 2014). It is assumed that the older the farmer is, the more experienced they are. These authors, also reported the results that indicated a positive relationship between age and market participation. Other authors (Pote and Obi, 2007) confirmed the existence of a positive association between age and market participation. The objective of this study was to find out whether age affects the smallholder farmers' participation in the agro-processing industries. The outcome confirms that age is statistically significant to influence the smallholder farmers' participation in the agroprocessing industries. In model $\mathrm{A}$, it was found that age was 1.082 times more likely to influence participation of smallholder farmers in the agro-processing when the availability of information, investment (bonds), mutual trust, and access to study groups were held constant. On the contrary, the effect of age on the participation of smallholder farmers in agro-processing industries was slightly reduced (1.074) after the access to the study group variable was removed in the model. Although the effect of age was reduced, it remains statistically significant to explain the participation of smallholder farming in the agro-processing industries.

\section{c) Effect of access to a study group on the smallholder farmers' participation}

A study group for smallholder farmers was introduced as a practice that seeks to promote sustainable agriculture (Zeweld et al., 2017). According to these authors, this strategy was introduced after realising some deficiency in the understanding of socio-psychological behaviour of smallholder farmers which had some negative impact on their adoption of 
technological innovations. Tallam et al. (2016) indicated that farmer groups (study group) are basic socio-economic safety nets for rural communities in Sub-Saharan Africa. According to these authors, these groups provide mutual support to farmers through collective action to enhance improvement of livelihoods. The question is: can access to study group affect the smallholder farmers' participation in the agro-processing industries of Gauteng Province? This study found that access to study groups does affect the participation of smallholder farming in agro-processing. However, its effects appear to be negative. This effect implies that as the smallholder farmers increase their involvement in the study group, they reduce their participation in agro-processing industries by 0.397 folds adjusting for the effect of other variables in the model. This effect appears to indicate that extension officers should use the study group with caution if they intend to ensure that farmers are involved in the agroprocessing industries.

\section{CONCLUSION/RECOMMENDATIONS}

The study aimed to identify factors that could be used as parameters to improve the smallholder farmers' participation in the agro-processing industries in Gauteng Province. The objective of identifying these parameters was to ensure that smallholder farmers can participate in the agroprocessing industries and thereby reaping the economic benefits such as job creation and selfemployment. In a nutshell, the study successfully identified five parameters (i.e., the availability of information, investment, mutual trust, age of the farmers, and access to study group) that were significant in influencing the participation of the smallholder farmers in the agro-processing industries. Of the five parameters, only access to study group was negatively correlated with the participation of smallholder farming in agro-processing in model $\mathrm{A}$. Consequently, access to the study group was excluded in the model B.

The study concluded that in order to reverse the skewed participation of the previously disadvantaged smallholder farmers in the ago-processing industry, the factors identified could be used to select participants in these industries. The selection of the participant should also be coupled with the promotion of market access, technology adoption, skills development, and adequate infrastructure, and some incentives to participate in the existing agro-processing industries. Considering these industries are owned by a few role players who may not easily allow the transformation to take place because of uncertainty and risk aversion. It may be a good idea for the province to develop a dedicated smallholder farmer agro-processing industry. The development of such an industry may require new policies that may specify criteria for participation and food safety standards to adhere to.

Should the participation of smallholder farmers in the agro-processing value chain improve, some of these farmers will be able to derive the profit and thereby grow to be commercially viable? The growth of these farmers may be different, as outlined by differential advantage theory (Clark, 1940 and Wickham, 2004). The theory advocate that buyers and sellers associate on a more permanent basis in order to serve specific needs for specific buyers group. Secondly, it also indicates that industries are limited in their ability to increase prices. Moreover, lastly, industries may seek to improve products to make them more attractive to consumers. This theory appears to indicate that the involvement of smallholder farmers in the agro-processing value chain may give them competitiveness such that they could innovate the right products that may be attractive to the buyers.

Furthermore, these farmers may have a permanent association with the market. This strategy could reduce their inability to access sustainable and niche markets in the long term. The 
implication of this access to the market in this way may boost their economic contribution and thereby improve their capacity to employ more people in their agricultural sector.

The study recommends that for these farmers to improve their participation in agro-processing industries, the parameters should be part of the agro-processing strategy, policy, and models. The capacity building initiatives should, amongst others, include these parameters. Therefore, Gauteng Province should prioritize these parameters in its effort to enhance the transformation of the agro-processing industries. Future research could investigate the impact of the identified parameters along with the commodity classifications and also in various regions of Gauteng Province. It may also be interesting to have studies that could look at agro-processing participation of smallholder farmers in both formal and informal markets with the view to test the parameters along with the different market segments

\section{ACKNOWLEDGEMENT}

We wish to acknowledge the Gauteng Department of Agriculture and Rural Development (GDARD) and the National Agricultural Marketing Council (NAMC) for their support.

\section{REFERENCES}

BALOCH, M.A. AND THAPA, G.B. 2019. Review of the agricultural extension modes and services with the focus to Balochistan, Pakistan. Journal of the Saudi Society of Agricultural Sciences, 18(2), pp.188-194.

BLACK, A., EDWARDS, L., GORVEN, R. AND MAPULANGA, W. 2020. Agro-processing, value chains, and regional integration in Southern Africa. WIDER Working Paper 2020/36.United Nations University. UNU-WIDER 2020.

BRANDSA, 2014. Huge potential' in SA's agro-processing industry. https://www.brandsouthafrica.com/investments-immigration/business/economy/agroprocessing-110314 (Accessed on the 15th of February 2017). Pp.1.

CAI, J., JIA, Y., HU, R. AND ZHANG, C. 2020. Four decades of China'sChina's agricultural extension reform and its impact on agents'agents' time allocation. Australian Journal of Agricultural and Resource Economics 66, pp. 104-125.

CLARK, C. 1940. The conditions of economic progress. London: Macmillan \& Co. Ltd.

DAFF. 2012. Economic profile of the agro-processing Industry in South Africa: 1970-2010. Department of Agriculture, Forestry and Fisheries. Arcadia, Pretoria. Republic of South Africa (RSA). Pp. 1-15

DAFF. 2016a. Agro-processing Quarterly Brief: No. 3, 2016. Department of Agriculture, Forestry and Fisheries. Arcadia, Pretoria. Republic of South Africa (RSA).pp. 1-14

DAFF. 2016. National Policy Framework on the support and development of small and medium Agro-Processing Enterprises in the Republic of South Africa .2014/30. Department of Agriculture, Forestry and Fisheries. Arcadia, Pretoria. Republic of South Africa (RSA). Pp. 1-12

DIMANT T, LEBONE K, MACKAY G, MOLOI L, NDEBELE T, PHUNG R. AND VAN HEERDEN G. 2016. South Africa survey. Institute of race relations, Johannesburg, Republic of South Africa. Pp. 1-5.

FEYAERTS, H., VAN DEN BROECK, G. AND MAERTENS, M. 2020. Global and local food value chains in Africa: A review. Agricultural Economics, 51(1), pp.143-157.

GDARD. 2015. Gauteng agro-processing strategy. Final Draft (October 2015). Johannesburg, RSA. 
GEBREHIWET, Y. AND MATHIBELI, K. 2013. Trade profile of South Africa's agroprocessing products to BRIC countries. Department of Agriculture, Forestry and Fisheries. Arcadia, Pretoria. Republic of South Africa (RSA).

HU, D., REARDON, T., ROZELLE, S., TIMMER, P. AND WANG, H. 2004. The emergence of supermarkets with Chinese characteristics: challenges and opportunities for China's agricultural development. Development policy review, 22(5), pp.557-586.

HU, R., CAI, Y., CHEN, K.Z., AND HUANG, J. 2012. Effects of inclusive public agricultural extension service: Results from a policy reform experiment in western China. China Economic Review, 23(4), pp.962-974.

HU, R., CAI, Y., CHEN, K.Z., CUI, Y. AND HUANG, J. 2010. Effects of Inclusive Public Agricultural Extension Service. Discussion paper 01037. International Food Policy Research Institute.

HU, R., ZHIJIAN, Y.A.N.G., KELLY, P. AND HUANG, J. 2009. Agricultural extension system reform and agent time allocation in China. China Economic Review, 20(2), pp.303-315.

HUANG, J., YANG, J. AND ROZELLE, S. 2010. China's agriculture: drivers of change and implications for China and the rest of world. Agricultural Economics, 41, pp.47-55.

KHOZA, T.M., SENYOLO, G.M., MMBENGWA, V.M., SOUNDY, P. AND SINNETT, D. 2019. Socio-economic factors influencing smallholder farmers'farmers' decision to participate in the agro-processing industry in Gauteng province, South Africa. Cogent Social Sciences, 5(1), p.1664193

MABE, L.K., AND OLADELE, O.I. 2020. Application of Information Communication Technologies for Agricultural Development through Extension Services: A Review. In Environmental and Agricultural Informatics: Concepts, Methodologies, Tools, and Applications (pp. 182-232). IGI Global.

MAPONYA, P., MODISE, D., VAN DEN HEEVER, E., MAHLANGU, S., BALOYI, N., MALULEKE, R. AND MPHAHLELE, M. 2014. The Establishment of Vegetable and Fruit Markets and Nurseries: A Case Study in the Greater Sekhukhune District, Limpopo Province, South Africa. Journal of Agricultural Science, 6(9), 144.

MAZUNGUNYE, P. 2019. "Industrialisation for economic transformation: Economy-wide impacts of agro-processing development in Tanzania." SA-TIED Working Paper 2019/42. Helsinki: UNU-WIDER.

MMBENGWA, V.M., RAMUKUMBA, T., GROENEWALD, J.A., VAN SCHALKWYK, H.D., GUNDIDZA, M.B. AND MAIWASHE, A.N. 2011. Evaluation of essential capacities required for the performance of farming small, micro and medium enterprise (SMEs) in South Africa. African Journal of Agricultural Research, 6(6), pp.1500-1507.

OLADELE, O. I. 2011. Contribution of Indigenous Vegetables and Fruits to Poverty Alleviation in Oyo State, Nigeria. Journal of Human Ecology, 34(1), 1-6.

OLOFSSON, M. 2020. Socio-economic differentiation from a class-analytic perspective: The case of smallholder tree-crop farmers in Limpopo, South Africa. Journal of Agrarian Change, 20(1), pp.37-59.

OWOO, N.S., AND M.P. LAMBON-QUAYEFIO. 2018. "Chapter 10: The Agro-Processing Industry and its Potential for Structural Transformation of the Ghanaian Economy", 192-212. In R.S. Newfarmer, J. Page, \& F. Tarp (eds), Industries without smokestacks: Industrialisation in Africa reconsidered. Oxford: Oxford University Press.

POTE, P.T. AND OBI, A. 2007. Technical constraints to smallholder agriculture and their implication for market access: Case study of Nkonkobe municipality, Eastern Cape, South Africa. Department of Agricultural Economics and Extension, University of Fort 
Hare, Alice, RSA.

TALLMAN, M.A., CARLSON, M.P., BRESSOUD, D.M. AND PEARSON, M. 2016. A characterization of calculus I final exams in US colleges and universities. International Journal of Research in Undergraduate Mathematics Education, 2(1), pp.105-133.

THINDISA, L.M.V. 2014. Participation by smallholder farming entrepreneurs in agroprocessing activities in South Africa (Masters Dissertation), University of Witwatersrand, Johannesburg, RSA.

ZEWELD, W., VAN HUYLENBROECK, G., TESFAY, G. AND SPEELMAN, S. 2017. Smallholder farmers' behavioural intentions towards sustainable agricultural practices. Journal of Environmental Management, 187, 71-81.

WICKHAM, P.A. 2004. Strategic entrepreneurship. Third Edition, Harlow, England. 
S. Afr. J. Agric. Ext.

Vol. 48 No.2, 2020: 153 - 165

Mmbengwa, Rambau, Rakuambo and Qin

http://dx.doi.org/10.17159/2413-3221/2020/v48n2a545

(License: CC BY 4.0) 